\title{
Effects of COVID-19 Pandemic on Treatment, Follow-up, and Lifestyle and Behavioral Characteristics in People Living with HIV
}

\author{
COVID-19 Pandemisinin HIV ile Yaşayan Bireylerde Takip, Tedavi, Yaşam Tarzı ve Davranış \\ Özelliklerine Etkisi
}

\author{
(D) Müge Ayhan ${ }^{1}$, (D) Bircan Kayaaslan², (1) Adalet Aypak1 ${ }^{1}$, (D) Rahmet Güner² \\ ${ }^{1}$ Ankara City Hospital, Clinic of Infectious Diseases and Clinical Microbiology, Ankara, Turkey \\ ${ }^{2}$ Ankara Yıldırım Beyazıt University, Ankara City Hospital, Clinic of Infectious Diseases and Clinical Microbiology, Ankara, Turkey
}

\section{Abstract}

Objectives: Limited available data currently indicate that the course of Coronavirus disease-2019 (COVID-19) in people living with human immunodeficiency virus (HIV) does not differ from people without HIV. During overstressing circumstances like pandemics, it is important to know how the population, especially special groups, are coping with such a major disaster. Measures and policies which are adopted according to this special patient group can change the quality of care in HIV patients. Health authorities have implemented some policies for elderly and special patient populations. In this study, it was aimed to evaluate the impact of the COVID-19 pandemic on treatment, follow-up and lifestyle and behavioral characteristics of HIV patients.

Materials and Methods: A phone survey was applied to all HIV patients who were followed regularly in our center. A total of 100 patients were included. The patients were asked about whether there was a disruption in follow-up and treatment. In addition, patient groups with and without anxiety were compared.

Results: Education level was higher and the duration of HIV infection was longer in the patient group with anxiety ( $p=0.01$ and $p=0.007$, respectively). The groups were compared for follow-up disruption. Disruption of follow-up was more frequent in retired, working and student patients ( $p=0.01$ ). Eighty-five percent stated that they adopted lifestyle and behavioral changes due to COVID-19.

Conclusion: Compliance with measures was sufficient and no patient was infected with the novel coronavirus. The appropriate measures and correct policies implemented by the authorities and patients' compliance with the protective measures have played a major role in ensuring the continuity of treatment of patients with chronic illnesses like HIV infection.

Key Words: COVID-19, HIV Infection, Treatment, Pandemic, Anxiety

\section{Öz}

Amaç: Mevcut sınırlı veriler, şu anda insan bağışıklık yetmezliği virüsü (HIV) ile yaşayan hastalarda Koronavirüs hastalığı-2019 (COVID-19) hastalığı seyrinin HIV ile enfekte olmayan bireylerden farklı olmadığını göstermektedir. Pandemi gibi aşırı strese neden olabilecek koşullarda, kişilerin özellikle de bazı özel hasta gruplarının böylesine büyük bir durumla nasıl başa çıktığını bilmek önemlidir. Bu hasta grubuna özel alınan önlemler ve politikalar, HIV hastalarının bakım kalitesini değiştirebilir. Sağlık otoriteleri, yaşılar ve özel hasta grupları için bazı politikalar uygulamıştır. Bu çalışmada, COVID-19 salgınının HIV hastalarının tedavi, takip ve yaşam tarzı ve davranış özellikleri üzerindeki etkisinin değerlendirilmesi amaçlanmıştır. Gereç ve Yöntem: Merkezimizde düzenli olarak takip edilen tüm HIV hastalarına telefonla anket uygulandı. Toplam 100 hasta dahil edildi. Hastalara takip ve tedavide aksama olup olmadığı soruldu. Ayrıca anksiyetesi olan ve olmayan hasta grupları bazı özellikler açısından karşılaştırıldı.

Bulgular: Anksiyetesi olan hasta grubunda eğitim düzeyi daha yüksek ve HIV enfeksiyonu süresi daha uzun izlendi (sırasıyla $p=0,01$ ve $p=0,007$ ). Gruplar takipte aksama açısından karşılaştırıldı. Emekli, çalışan ve öğrenci hastalarda takipte aksama daha sık bulundu ( $p=0,01)$. Hastaların \% $085^{\prime} i$ COVID-19 nedeniyle yaşam tarzı ve davranış değişiklikleri geliştirdiklerini belirtti.

Address for Correspondence/Yazışma Adresi: Müge Ayhan,

Ankara City Hospital, Clinic of Infectious Diseases and Clinical Microbiology, Ankara, Turkey

Phone: +90 5424187882 E-mail: dr.mugeayhan@ @ hotmail.com ORCID ID: orcid.org/0000-0002-4821-5559

Received/Geliş Tarihi: 21.12.2020 Accepted/Kabul Tarihi: 11.03.2021

๑Copyright 2021 Ankara University Faculty of Medicine

Journal of Ankara University Faculty of Medicine is published by Galenos Publishing House.

All content are under CC BY-NC-ND license. 
Sonuç: Tedbirlere uyum yeterliydi ve hastalardan hiçbirinde COVID-19 enfeksiyonu gelişmemişti. Yetkililer tarafından uygulanan yerinde önlemler ve doğru politikalar ve hastaların koruyucu önlemlere uyumu, HIV enfeksiyonu gibi kronik hastalıkları olan hastaların tedavisinin sürekliliğinin sağlanmasında önemli bir rol oynamaktadır.

Anahtar Kelimeler: COVID-19, HIV Enfeksiyonu, Tedavi, Pandemi, Anksiyete

\section{Introduction}

The new Coronavirus disease-2019 (COVID-19) emerged in Wuhan, China, in December 2019, was soon declared as a pandemic by the World Health Organization and became an important public health problem. It has various clinical syndromes, from mild infection to severe pneumonia resulting in respiratory failure and death. More than 10 million confirmed cases were reported worldwide and approximately 500,000 of them died (1-3). In Turkey, the first case was observed on March 11 and the first death was observed on March 17, 2020. A total of 10.613,035 people have been effected and 514,615 deaths were observed until early July, 2020 (4). From April 11 to June 1, a strict lockdown was applied to children and elderly, and a curfew was applied every weekend to the general population. Extra measures and policies like working multiple shifts, closing schools, prohibition of the entry of foreign nationals to the country, and implementation of quarantine were taken by the authorities to control the outbreak (5).

In current data, people aged above 60 years, of male gender at any age and those with comorbidities like diabetes, obesity, hypertension, cardiovascular disease, lung disease and chronic kidney disease present with more severe symptoms and worse prognosis $(6,7)$. Approximately 37.9 million people living with human immunodeficiency virus (HIV) (PLWH) are at high risk for getting new COVID-19. Also the COVID-19 pandemic has caused several barriers and challenges in HIV care, followup and treatment procedures (8). In an earlier series of 138 COVID-19 cases $1.4 \%$ of the patients were HIV patients (9). In Barcelona it was stated that only $1 \%$ of the COVID-19 patients were also HIV patients (10). The limited data currently available does not indicate that the course of COVID-19 in PLWH differs from that of people without HIV. Some of the HIV patients have other comorbidities which cause an increased risk of severity of COVID-19's course. But it is still unknown whether HIV infection causes higher risk of severe disease (11). During overstressing circumstances like the current pandemic, it is important to know how the population is coping with such a major disaster, especially special populations (12). In this study, we aimed to investigate the effect of COVID-19 pandemic on treatment, follow-up and changes in lifestyle and behavioral characteristics of HIV patients.

\section{Materials and Methods}

This study was designed as a phone-based questionnaire study. It was performed between 1-15 June 2020. All HIV patients who are followed up regularly in our center were evaluated (Figure 1). Adults older than 18 years of age who agreed to participate in the study were included. No payment was given to the participants for participating the survey.

\section{Data collection}

A standard questionnaire form was prepared. A pilot study was conducted with 25 patients to verify the clarity of the questionnaire (included in the final sample). The questionnaire consists of a total of 38 questions (16 about demographic features and medical history, 7 about follow-up and HIV treatment during COVID-19 pandemic, 3 about anxiety of contracting COVID-19, 12 questions about lifestyle and

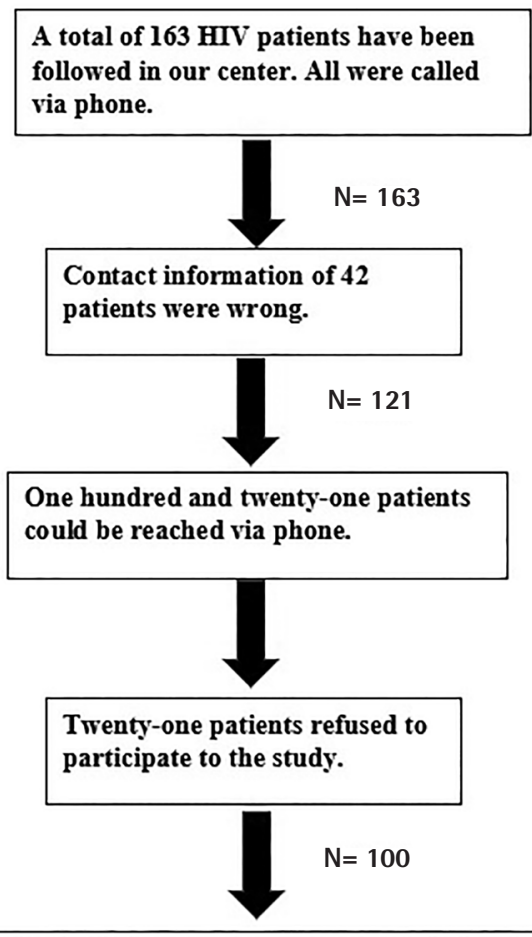

A total of 100 patients were included to the study.

Figure 1: Flowchart of inclusion of patients to the study HIV: Human immunodeficiency virus 
behavioral changes during pandemic). Two researchers called every patient and after receiving informed consent, applied the complete questionnaire.

\section{Ethical considerations}

The study protocol and the informed consent of the study were approved by Ankara City Hospital Clinical Researchs Ethics Committee No:1. All patients were informed about the study and content of the survey; verbal consent was taken by answering a yes-no question. Personal and identity information of patients were separated from the questionnaire and data were analyzed anonymously.

\section{Statistical Analysis}

SPSS 18.0 (IBM Inc., Armonk, NY) software system was used for the statistical analyses in the study. Categorical variables were described as number and their percentages. Mean, standard deviation, median, and range (minimum-maximum) were used for describing continuous variables. For categorical variables, the $\chi^{2}$ test was used, or Fisher's exact test was used when the data did not meet parametric test conditions. Continuous variables were analyzed with t-tests when the data were normally distributed, and Mann-Whitney $U$ test was used when parametric test conditions were not met. A p-value of $<0.05$ was accepted as statistically significant.

\section{Results}

One hundred and sixty-three HIV patients had available contact information. All of them were called via phone. The contact information of 42 patients was incorrect or changed, 121 of the patients were reached. Of these, $100(82.6 \%)$ accepted to participate in this study. A total of 89 males and 11 females were recruited into the study. The mean age of participants was $39.45 \pm 12.1$ years. Of the participants, $62(62 \%)$ had an education level of high school or higher, and 20 of them had at least one additional comorbid disease. Nine of the patients were taking medication in addition to HIV treatment. None of the patients had a COVID-19 diagnosis.

Mean duration of HIV diagnosis was $2.8 \pm 2.0$ years. Fourteen patients (14\%) had an HIV positive person in their family. The most common used HIV treatment regimens were the combinations of elvitegravir-cobicistat + tenofovir alafenamide/ emtricitabine, and tenofovir disoproxyl fumarate/emtricitabine + dolutegravir (Table 1).

Patient worry over contracting COVID-19 was investigated. Patients with and without anxiety were compared in terms of demographic and clinical features. Sixty-eight patients had anxiety about COVID-19. Sex, age groups, occupational status, presence of a comorbidity were similar between two groups. Educational level and duration of HIV infection were significantly different in patients with or without anxiety

\begin{tabular}{ll} 
Table 1 : HIV follow-up characteristics & \\
\hline Duration of disease, years, mean \pm SD & $\mathbf{2 . 8 \pm 2 . 0}$ \\
\hline Family history, $\mathrm{n}(\%)$ & $14(14 \%)$ \\
\hline Treatment regimens, $\mathrm{n}(\%)$ & \\
\hline EVG/c/FTC/TAF & $54(54 \%)$ \\
\hline TDF/FTC +DTG & $28(28 \%)$ \\
\hline DTG/ABC/3TC & $11(11 \%)$ \\
\hline Others & $7(7 \%)$ \\
\hline
\end{tabular}

HIV: Human immunodeficiency virus, SD: Standard deviation, EVG: Elvitegravir, c: Cobicistat, FC: Emtricitabine, TAF: Tenofovir alafenamide fumarate, TDF: Tenofovir disoproxil fumarate, DTG: Dolutegravir, ABC: Abacavir, 3TC: Lamivudine

( $p=0.01$ and $p=0.007$ respectively) (Table 2 ). Educational level and duration of HIV infection was higher in patients with anxiety.

Treatment discontinuation was observed in only ten of the patients but disruption in follow-up was seen in a total of sixty-nine patients, 64 of which were due to the COVID-19 pandemic. The most common reasons given about follow-up disruption during the pandemic were that they were afraid of getting COVID-19 if they go to a hospital (40.5\%) and that their doctor might be inaccessible in the hospital (37\%) (Table 3). Risk factors for disruption in follow-up were evaluated (Table 4). The only statistically significant and negatively affecting risk factor was occupational status. Disruption of follow-up was more frequent in retired, working, and student patients $(p=0.01)$. Patients were asked about their behavioral and lifestyle changes during the pandemic. A majority of patients (85\%) stated that they had a change in their lifestyle and increase in frequency of hand washing, use of hand disinfectants and masks (70\%). Sixty-seven of the patients stated that they avoided crowded areas and stayed at home except during urgent and necessary situations (Table 5).

\section{Discussion}

The COVID-19 pandemic has rapidly evolved and is ongoing. It is placing an overwhelming burden on healthcare systems and authorities to respond with effective and appropriate interventions, measures, and policies. The critical factor in reducing infection and stopping the spread of the virus is to create rapid and widespread behavioral change (13). While the pandemic itself is enough of a cause of stress and anxiety, social distancing and home isolation may have caused additional pressure on people. This situation has been observed in previous pandemics. Approximately $35 \%$ of individuals developed anxiety and depressive symptoms during the severe acute respiratory syndrome pandemic (14). PLWH already have a higher frequency of anxiety disorder than the general population $(10,14)$. Median incidence of anxiety disorders among PLWH was reported higher from the general population in a previous study, 


\begin{tabular}{|c|c|c|c|}
\hline Patient's characteristics, n (\%) & $\begin{array}{l}\text { Patients with anxiety about pandemic } \\
(\mathrm{n}=68)\end{array}$ & $\begin{array}{l}\text { Patients without anxiety about pandemic } \\
(\mathrm{n}=32)\end{array}$ & $\mathbf{p}$ \\
\hline \multicolumn{4}{|l|}{ Sex } \\
\hline Male & $60(67.4 \%)$ & $29(32.5 \%)$ & 0.9 \\
\hline Female & $8(72.7 \%)$ & $3(27.2 \%)$ & \\
\hline \multicolumn{4}{|l|}{ Age groups } \\
\hline $18-30$ & $23(85.1 \%)$ & $4(14.8 \%)$ & \\
\hline $31-40$ & $17(56.6 \%)$ & $13(43.3 \%)$ & \\
\hline $41-50$ & $15(65.2 \%)$ & $8(34.7 \%)$ & \\
\hline$>50$ & $13(65 \%)$ & $7(35 \%)$ & 0.1 \\
\hline \multicolumn{4}{|l|}{ Education level } \\
\hline Primary education & $20(52.6 \%)$ & $18(47.3 \%)$ & \\
\hline High school and higher education & $48(77.4 \%)$ & $14(22.5 \%)$ & 0.01 \\
\hline \multicolumn{4}{|l|}{ Occupational status } \\
\hline Working & $31(63.2 \%)$ & $18(36.7 \%)$ & \\
\hline Not-working & $5(62.5 \%)$ & $3(37.5 \%)$ & 0.6 \\
\hline Student & $5(83.3 \%)$ & $1(16.6 \%)$ & \\
\hline Retired & $27(72.9 \%)$ & $10(27 \%)$ & \\
\hline Any comorbidity & $10(50 \%)$ & $10(50 \%)$ & 0.7 \\
\hline $\begin{array}{l}\text { Duration of HIV infection, years, mean } \\
\pm \mathrm{SD}\end{array}$ & $3.1 \pm 2.217$ & $2 \pm 1.344$ & 0.007 \\
\hline
\end{tabular}

\begin{tabular}{|c|c|}
\hline \multicolumn{2}{|c|}{$\begin{array}{l}\text { Table 3: Discontinuance of follow-up and treatment in HIV } \\
\text { patients }(n=100)\end{array}$} \\
\hline $\begin{array}{l}\text { Presence of discontinuation of treatment during } \\
\text { COVID-19 pandemic, } n(\%)\end{array}$ & $10(10 \%)$ \\
\hline Presence of disruption of follow-up, $n(\%)$ & $69(69 \%)$ \\
\hline Associated with COVID-19 pandemic & $64(92 \%)$ \\
\hline Not-associated with COVID-19 pandemic & $5(8 \%)$ \\
\hline \multicolumn{2}{|l|}{$\begin{array}{l}\text { Reasons of follow-up disruption during } \\
\text { COVID-19 pandemic }\end{array}$} \\
\hline I was afraid of getting COVID-19 if I go to hospital & $28(40.5 \%)$ \\
\hline I stayed at home because I'm immunosupressed & $0(0 \%)$ \\
\hline $\begin{array}{l}\text { I thought that the disruption in my follow-up } \\
\text { wouldn't be a problem }\end{array}$ & $3(4 \%)$ \\
\hline $\begin{array}{l}\text { I thought I couldn't reach my doctor in the } \\
\text { hospital }\end{array}$ & $26(37 \%)$ \\
\hline $\begin{array}{l}\text { I called my doctor and he/she postponed my } \\
\text { appointment to another time }\end{array}$ & $7(10 \%)$ \\
\hline
\end{tabular}

COVID-19: Coronavirus disease-2019, HIV: Human immunodeficiency virus

$22.85 \%$ and $18 \%$ respectively (15). In a questionnaire study from Italy conducted in patients who have common-variable immunodeficiency, $42.3 \%$ of the patients were found to be at risk for anxiety about COVID-19 (16). In our study, anxiety of HIV patients about getting COVID-19 was observed in 68\% of the patients. It was also observed that these patients' anxiety caused them to disrupt their follow-up. Recent data regarding the course of COVID-19 in PLWH does not indicate a difference from the general population without HIV. However, PLWH who have another comorbidity like hypertension, diabetes, malignancy or obesity which increases the risk of COVID-19 may face an increase in severity or a worse course of disease (11).

In our study, anxiety was more frequent in people with higher education level $(p=0.01)$. In a cross sectional study including 3,388 participants, education was found to be significantly associated with more knowledge about COVID-19 (17). It is possible that in our study as well, better knowledge about the disease in higher educated people may have caused more anxiety about the disease and its course. We also found that the mean duration of HIV disease was higher in patients with anxiety than patients without anxiety. As patients' knowledge and experience about HIV infection increased, their concerns and anxiety about COVID-19 may also have increased.

In our study a total of 69 patients disrupted their followup, sixty-four because of the COVID-19 pandemic. The most common reasons for disrupting the treatment were fear of getting COVID-19 when they came to the hospital and thinking that they could not reach their doctor. The only significant risk factor for disruption in follow-up was occupational status. Disruption was observed in a higher percentage of working, retired and student patients. It was postulated that the retired population disrupted their follow-up due to the strict lockdown 


\begin{tabular}{|c|c|c|c|}
\hline & $\begin{array}{l}\text { Patients with disruption in follow-up } \\
(n=64)\end{array}$ & $\begin{array}{l}\text { Patients without disruption in follow-up } \\
(n=36)\end{array}$ & $\mathbf{p}$ \\
\hline \multicolumn{4}{|l|}{ Sex } \\
\hline Male & $56(62.9 \%)$ & $33(37 \%)$ & \multirow{2}{*}{0.5} \\
\hline Female & $8(72.7 \%)$ & $3(27.2 \%)$ & \\
\hline \multicolumn{4}{|l|}{ Age groups, n (\%) } \\
\hline $31-40$ & $21(70 \%)$ & $9(30 \%)$ & 0.6 \\
\hline $41-50$ & $16(69.5 \%)$ & $7(30.4 \%)$ & \\
\hline$>50$ & $12(60 \%)$ & $8(40 \%)$ & \\
\hline \multicolumn{4}{|l|}{ Education level, n (\%) } \\
\hline Working & $38(77.5 \%)$ & $11(22.4 \%)$ & \\
\hline Not-working & $2(25 \%)$ & $6(75 \%)$ & \\
\hline Student & $4(66.6 \%)$ & $2(33.3 \%)$ & 0.01 \\
\hline Retired & $20(54 \%)$ & $17(45.9 \%)$ & \\
\hline Presence of any comorbidity, n (\%) & $9(64.2 \%)$ & $5(35.7 \%)$ & 0.9 \\
\hline $\begin{array}{l}\text { Duration of HIV infection, years, } \\
\text { mean } \pm \text { SD }\end{array}$ & $3 \pm 2.197$ & $2.42 \pm 1.713$ & 0.8 \\
\hline $\begin{array}{l}\text { Anxiety about COVID-19 pandemic, } \\
\mathrm{n}(\%)\end{array}$ & $44(64.7 \%)$ & $24(35.2 \%)$ & 0.1 \\
\hline
\end{tabular}

\begin{tabular}{|c|c|}
\hline Questions asked to the participants & n (\%) \\
\hline Change in lifestyle & $85(85 \%)$ \\
\hline $\begin{array}{l}\text { Staying away from meetings, social environment/ } \\
\text { relatives, and friends }\end{array}$ & $46(46 \%)$ \\
\hline Increase in time for resting & $70(70 \%)$ \\
\hline Any change in nutritional habits & $27(27 \%)$ \\
\hline Using vitamins or herbal supplements & $16(16 \%)$ \\
\hline $\begin{array}{l}\text { Increase in frequency of hand washing and use of } \\
\text { masks and hand disinfectants }\end{array}$ & $70(70 \%)$ \\
\hline Staying away from crowded places & $67(67 \%)$ \\
\hline Avoiding public transportation & $41(41 \%)$ \\
\hline Using markets for buying daily goods & $20(20 \%)$ \\
\hline Using internet shopping more frequently & $27(27 \%)$ \\
\hline Working from home & $20(20 \%)$ \\
\hline $\begin{array}{l}\text { Staying at home except in urgent and necessary } \\
\text { situations }\end{array}$ & $67(67 \%)$ \\
\hline
\end{tabular}

which was applied to children, youth and the elderly. Despite the high disruption frequency, discontinuation occurred in only 10 of the patients. The Turkish government enforced important measures to combat the pandemic. Because hospitals are one of the most risky areas for the spread of the COVID-19, one of the most important measures was that people who have chronic diseases and used drugs regularly for these diseases could procure their medications from pharmacies without any need for prescription or drug using reports. Their medications were provided based on their medical records in the healthcare system (18). In this way, treatment discontinuation was lower than the disruption in follow-up. Lifestyle and behavioral changes during pandemic were also asked to patients. A majority of the patients expressed a change in their lifestyle. Most of them stated that they stayed away from crowded places and stayed at home except for urgent and necessary situations. None of the patients who were included in the study were diagnosed with COVID-19. This was thought to be related to high compliance with social distancing and home isolation remedies. Nutritional change or use of supplementary drugs or herbal remedies were lower in our study population.

In truth, we do not know the real impact of COVID-19 in PLWH because of the fact that HIV patients are more vigilant at social distancing and home isolation because of the fear of higher acquisition rates and a worse outcome of COVID-19 (10). Larger-scale cohort studies will be beneficial to understand the 
burden of disease in PLWH. But we know that the COVID-19 outbreak has caused, and further outbreaks will continue to cause significant anxiety in PLWH or similar specific populations. Supporting people with accurate and appropriate information about diseases as well as the measures and the lifestyle changes that should be applied for protection are needed in case of similar outbreaks.

\section{Conclusion}

This study aimed to evaluate the effect of the COVID-19 pandemic on the treatment, follow-up and changes in lifestyle and behavioral characteristics of HIV patients. Although the number of participants of the study was low, it was observed that patients were adequately compliant with protective measures. We found higher education level and higher duration of HIV infection was associated with higher anxiety in patients. Education of such specific patient groups with accurate and appropriate information has great importance. Appropriate measures and correct policies implemented by the authorities play a major role in ensuring the continuity of treatment of patients with chronic illnesses like HIV infection. We think that carrying out further large-scale studies on the mental burden of the disease on specific populations will be an important addition to studies on diagnosing and treating COVID-19.

\section{Acknowledgements}

We would like to thank Betül Kaplan for contribution to our study.

Ethics

Ethics Committee Approval: The study protocol was approved by Ankara City Hospital Clinical Researchs Ethics Committee No:1.

Informed Consent: All patients were informed about the study and content of the survey; verbal consent was taken by answering a yes-no question.

Peer-reviewed: Externally peer-reviewed.

\section{Authorship Contributions}

Surgical and Medical Practices: M.A., B.K., A.A., Concept: M.A., B.K., R.G., Design: B.K., R.G., Data Collection or Processing: M.A., B.K., A.A., Analysis or Interpretation: M.A., B.K., A.A., R.G., Literature Search: M.A., B.K., Writing: M.A., B.K.

Conflict of Interest: The authors declare that there is no conflict of interest.
Financial Disclosure: The authors declared that this study received no financial support.

\section{References}

1. Zhou M, Zhang X, Qu J. Coronavirus disease 2019 (COVID-19): a clinical update. Front Med. 2020;14:126-135.

2. Mungroo MR, Khan NA, Siddiqui R. Novel Coronavirus: Current Understanding of Clinical Features, Diagnosis, Pathogenesis, and Treatment Options. Pathogens. 2020;9:297.

3. Cucinotta D, Vanelli M. WHO Declares COVID-19 a Pandemic. Acta Biomed. 2020;91:157-160.

4. COVID-19 Coronavirus Pandemic. https://www.worldometers.info/ coronavirus/ (2020)

5. Demirbilek Y, Pehlivantürk G, Özgüler ZÖ, et al. COVID-19 outbreak control, example of ministry of health of Turkey. Turk J Med Sci. 2020;50:489-494.

6. Blanco JL, Ambrosioni J, Garcia F, et al. COVID-19 in patients with HIV: clinical case series. Lancet HIV. 2020;7:314-316.

7. Laurence J. Why Aren't People Living with HIV at Higher Risk for Developing Severe Coronavirus Disease 2019 (COVID-19)? AIDS Patient Care STDS. 2020;34:247-248.

8. Jiang $H$, Zhou $Y$, Tang W. Maintaining HIV care during the COVID-19 pandemic. Lancet HIV. 2020;7:308-309.

9. Wang D, Hu B, Hu C, et al. Clinical Characteristics of 138 Hospitalized Patients With 2019 Novel Coronavirus-Infected Pneumonia in Wuhan, China. JAMA. 2020;323:1061-1069.

10. Jones R, Nelson M, Bracchi, M, Asboe, D, Boffito M. COVID-19 in patients with HIV. Lancet HIV 7, e383 (2020).

11. Interim Guidance for COVID-19 and Persons with HIV. https://aidsinfo. nih.gov/guidelines/html/8/covid-19-and-persons-with-hiv--interimguidance-/554/interim-guidance-for-covid-19-and-persons-with-hiv.

12. Zhang Y, Ma ZF. Impact of the COVID-19 Pandemic on Mental Health and Quality of Life among Local Residents in Liaoning Province, China: A CrossSectional Study. Int J Environ Res Public Health. 2020;17:2381.

13. Betsch C, Wieler LH, Habersaat K; COSMO group. Monitoring behavioural insights related to COVID-19. Lancet. 2020;395:1255-1256.

14. Cheng SK, Wong CW, Tsang J, et al. Psychological distress and negative appraisals in survivors of severe acute respiratory syndrome (SARS). Psychol Med. 2004;34:1187-1195.

15. Brandt C, Zvolensky MJ, Woods SP, et al. Anxiety symptoms and disorders among adults living with HIV and AIDS: A critical review and integrative synthesis of the empirical literature. Clin Psychol Rev. 2017;51:164-184.

16. Pulvirenti $F$, Cinetto $F$, Milito $C$, et al. Health-Related Quality of Life in Common Variable Immunodeficiency Italian Patients Switched to Remote Assistance During the COVID-19 Pandemic. J Allergy Clin Immunol Pract. 2020;8:1894-1899.

17. Al-Hanawi MK, Angawi K, Alshareef N, et al. Knowledge, Attitude and Practice Toward COVID-19 Among the Public in the Kingdom of Saudi Arabia: A Cross-Sectional Study. Front Public Health. 2020;8:217.

18. Kronik Hastalığı Bulunan Sigortalılarımızın Sağlık Raporları ve Reçeteleri İkinci Bir Duyuruya Kadar Geçerli Sayılacak. https://web.archive.org/save/ https://www.ailevecalisma.gov.tr/tr-tr/haberler/bakan-selcuk-kronikhastaligi-bulunan-sigortalilarimizin-saglik-raporlari-ve-receteleri-ikincibir-duyuraya-kadar-gecerli-sayilacak/. 